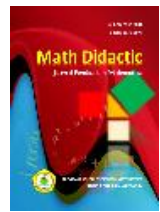

MATH DIDACTIC: JURNAL PENDIDIKAN MATEMATIKA

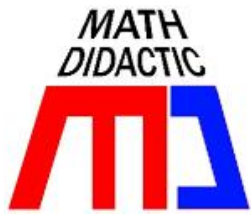

\title{
PERBANDINGAN MODEL PEMBELAJARAN KOOPERATIF TIPE COURSE REVIEW HORRAY DAN STAD TERHADAP PENINGKATAN PEMAHAMAN MATEMATIS SISWA
}

\section{COMPARISON OF COOPERATIVE LEARNING MODELS OF TYPE COURSE REVIEW HORRAY AND STAD TO INCREASING STUDENTS OF MATHEMATICAL UNDERSTANDING}

\author{
Bettri Yustinaningrum, Leni Agustina Daulay, Dina Yulisa Putri \\ Tadris Matematika STAIN Gajah Putih Takengon \\ bettri_yustinaningrum@yahoo.com, agustina_leni@yahoo.com,dinayulisaputri@gmail.com
}

\begin{abstract}
Abstrak: Tujuan penelitian ini adalah untuk (1) membandingkan antara model pembelajaran Course Review Horay (CRH) dengan STAD dalam meningkatkan pemahaman matematis siswa, (2) mendeskripsikan peningkatan pemahaman matematis siswa yang menggunakan CRH dan STAD, (3) mengetahui keterlaksanaan model pembelajaran Course Review Horay (CRH) dengan STAD melalui kegiatan pengamatan aktivitas guru dan siswa. Bentuk penelitian ini adalah Penelitian kuantitatif dengan jenis penelitian semi ekperimen. Sample penelitian dipilih dengan Cluster Random Sampling diperoleh dua kelas siswa X IPA 2 dan X IPA 3 SMA N 15 Takengon. Teknik pengumpulan data yang digunakan adalah tes dan observasi. Uji hipotesis menggunakan uji-t 1 pihak dan peningkatan menggunakan uji N-gain. Hasil penelitian diperoleh thitung $>$ ttabel dimana 2,44 $>2,01$, dengan taraf signifikan $0,05 \mathrm{dan} \mathrm{dk}=26+26-2=50$, dengan demikian H0 ditolak dan Ha diterima. Peningkatan kemampuan pemahaman matematis yang menggunakan model pembelajaran CRH lebih signifikan sebesar $g=$ 0,66 dibanding dengan STAD sebesar $g=0,33$. Berdasarkan hasil penelitian ini dapat disimpulkan bahwa model pembelajaran Course Review Horay (CRH) lebih baik dari STAD dalam meningkatkan pemahaman matematis siswa.
\end{abstract}

Kata Kunci: Course Review Horray (CRH), STAD, Pemahaman Matematis

Abstract: The purpose of this study was to (1) compare the Course Review Horay (CRH) learning model with STAD in improving students' mathematical understanding, (2) describe the increase in mathematical understanding of students using CRH and STAD, (3) find out the feasibility of the Course Review Horay learning model (CRH) with STAD through activities of observing teacher and student activities. The form of this research is quantitative research with semi-experimental research types. The research sample was selected by Cluster Random Sampling obtained by two classes of students X Science 2 and X IPA 3 Takengon N 15 High School. Data collection techniques used are tests and observations. Hypothesis testing uses a 1-party t-test and an increase using the $N$-gain test. The results obtained by tcount $>$ t table where 2.44>2.01, with a significant level of 0.05 and $d k=26+26-2=50$, thus $H O$ is rejected and Ha is accepted. The increase in the ability of mathematical understanding using the CRH learning model is more significant at $g=0.66$ compared to STAD at $g=0.33$. Based on the results of this study it can be concluded that the Course Review Horay (CRH) learning model is better than STAD in improving students' mathematical understanding.

Keywords: Course Review Horray (CRH), STAD, Mathematical Understanding

Cara Sitasi: Yustinaningrum, B., Daulay, L.A., \& Putri, D.Y. (2019). Perbandingan model pembelajaran kooperatif tipe course review horray dan STAD terhadap peningkatan pemahaman matematis siswa. Math Didactic: Jurnal Pendidikan Matematika, 5(1), 43-51. https://doi.org/10.33654/math.v5i1.285 
Matematika merupakan materi ajar yang sangat penting, namun pada umumnya matematika kurang disukai oleh siswa hal ini dikarenakan di dalam matematika terdapat konsep-konsep dan prinsip-prinsip yang sukar dipelajari siswa padahal matematika mengajarkan untuk berpikir logis, rasional, cermat dan efektif yang sangat berguna sekarang dan yang akan datang (Suherman, 2002). Matematika diakui penting dipelajari, tetapi sulit dipelajari, maka tidak jarang siswa tidak menyukai pelajaran matematika. Fenomena ini terus berlangsung pada setiap jenjang pendidikan, yang berakibat pada terakumulasinya rasa ketidaktahuan dan ketidakberartian mata pelajaran matematika. Kondisi ini, menyebabkan pelajaran matematika menjadi semakin tidak disenangi, tidak diperlukan dan bahkan diabaikan, sehingga hasil belajar matematika secara umum masih rendah. Melalui pemilihan model, strategi mengajar, dan pendekatan yang tepat dan kemampuan pemahaman siswa yang terbangun, guru dapat membantu mengurangi sifat abstrak dari objek matematika, sehingga siswa mampu menangkap pelajaran matematika yang diajarkan tanpa diiringi rasa takut, perasaan sulit, bosan dan sebagainya, melainkan terwujudnya suasana yang menyenangkan. Berdasarkan hal tersebut, maka diharapkan guru dapat menjadi fasilitator yang bertugas mengkondisikan lingkungan untuk memberikan motivasi dan kemudahan dalam memahami materi pelajaran matematika bagi siswa. Untuk menghindari anggapan bahwa mata pelajaran matematika adalah mata pelajaran yang membosankan, sulit untuk dipahami, dan dianggap menakutkan oleh sebagian siswa, maka pembelajaran matematika diupayakan berlangsung alamiah dalam bentuk kegiatan siswa bekerja dan mengalami, bukan transfer pengetahuan dari guru dan siswa.

Tujuan penting dalam pembelajaran matematika adalah kemampuan pemahaman matematik itu sendiri. Kemampuan pemahaman matematika merupakan pemahaman yang mampu mengubah (translation) soal kata-kata ke dalam simbol dan sebaliknya, mampu mengartikan (interpretation) suatu kesamaan, mampu memperkirakan (extrapolation) suatu kecenderungan dari gambar (Ruseffendi, 1998). Pemahaman adalah suatu keadaan yang menunjukan sejauh mana siswa dapat menyelesaikan masalah dengan benar dengan caranya sendiri berdasarkan pengetahuan yang sudah didapatnya.

Hasil observasi siswa di SMA N 15 Takengon saat diberikan permasalahan sistem persamaan linear tiga variabel (SPLTV) menunjukkan hasil pemahaman matematis yang bervasiasi, bagi siswa yang memiliki kemampuan pemahaman matematis tinggi ia tidak akan mengalami kesulitan, sebaliknya bagi siswa yang memiliki kemampuan pemahaman matematis rendah ia akan sangat mengalami kesulitan. Berdasarkan hasil kerja siswa diperoleh kesimpulan bahwa siswa belum mampu memahami soal yang disajikan, belum mampu menggunakan, memanfaatkan, dan memilih prosedur atau operasi tertentu dari suatu konsep secara algoritma serta mengaplikasikannya dalam pemecahan masalah, belum dapat menentukan himpunan penyelesaiannya dengan benar.

Dari uraian di atas, maka salah satu upaya agar siswa dapat memahami materi yang diajarkan adalah dengan melibatkan siswa secara aktif dalam pelajaran matematika melalui model pembelajaran yang tepat. Model pembelajaran alternatif yang dapat digunakan oleh guru adalah model pembelajaran Course 
Review Horray (CRH) dan STAD. Menurut Kurniasih, model pembelajaran Course Review Horay merupakan model pembelajaran yang dapat menciptakan suasana kelas menjadi meriah dan menyenangkan karena setiap siswa yang dapat menjawab benar maka siswa tersebut diwajibkan berteriak "hore!" atau yelyel lainnya yang disepakati (Kurniasih, 2016). Model pembelajaran Course Review Horay (CRH) menuntut ketepatan siswa dalam mengisi jawaban pada lembar kerja siswa yang telah disediakan dan meningkatkan semangat belajar karena suasana pembelajaran berlangsung menyenangkan (Arahmah, Suharno, \& Sudiman, 2017). Model pembelajaran STAD merupakan salah satu pembelajaran kooperatif yang paling sederhana dan sangat baik untuk guru pemula ketika ingin menerapkan pembelajaran kooperatif yang terdiri atas lima komponen utama yaitu presentasi kelas, pembentukan tim, kuis, skor kemajuan individual, dan rekognisi tim (Slavin, 1995). Kelebihan STAD adalah melatih siswa dalam mengembangkan aspek kecakapan sosial di samping kecakapan kognitif dan peran guru juga menjadi lebih aktif dan lebih terfokus sebagai fasilitator, mediator, motivator dan evaluator (Isjoni, 2010). Kedua model pembelajaran memiliki kelebihan dalam meningkatkan pemahaman siswa. Penelitian ini bertujuan untuk membandingkan antara model pembelajaran CRH dengan STAD mana yang lebih baik dalam meningkatkan pemahaman matematis siswa pada materi sistem persamaan linear tiga variabel (SPLTV), mendeskripsikan peningkatan pemahaman matematis siswa yang menggunakan CRH dan STAD, (3) mengetahui keterlaksanaan model pembelajaran Course Review Horay (CRH) dengan STAD melalui kegiatan pengamatan aktivitas guru dan siswa.

\section{Metode Penelitian}

Penelitian ini menggunakan jenis penelitian semi eksperimen dengan pendekatan kuantitatif, dengan tujuan untuk membandingkan model pembelajaran kooperatif tipe CRH (Course Review Horray) dengan STAD dalam mengukur pemahaman matematis siswa pada materi sistem persamaan linear tiga variabel. Pengambilan sampel penelitian menggunakan cluster random sampling terpilih kelas $\mathrm{X}$ ipa 2 sebagai kelas ekperimen I dan siswa kelas X ipa 3 kelas eksperimen II. Desain penelitian menggunakan Pretest-Posttest Control Group Design. Seperti terlihat pada tabel 1.

Tabel 1. Pretest-Posttest Control Group Design

\begin{tabular}{llll}
$\mathbf{R}_{1}$ & $\mathbf{O}_{1}$ & $\mathbf{X}_{1}$ & $\mathbf{O}_{3}$ \\
$\mathbf{R}_{2}$ & $\mathrm{O}_{2}$ & $\mathrm{X}_{2}$ & $\mathrm{O}_{4}$ \\
\hline
\end{tabular}

Keterangan:

$\mathrm{R}_{1}$ dan $\mathrm{R}_{2}$ : Kelas Eksperimen I dan Kelas Eksperimen II

$\begin{array}{ll}\mathrm{X}_{1} & \text { : Model pembelajaran CRH } \\ \mathrm{X}_{2} & \text { : Model STAD } \\ \mathrm{O}_{1} \text { dan } \mathrm{O}_{2} & \text { : Pretest } \\ \mathrm{O}_{3} \text { dan } \mathrm{O}_{4} & \text { : Post-Test (Emzir, 2013) }\end{array}$

Teknik analisis data yang digunakan yaitu uji-t dan uji $\mathrm{N}$-gain yang digunakan untuk mendeskripsikan peningkatan kemampuan pemahaman matematis siswa menggunakan kedua model pembelajaran yaitu Model pembelajaran course review horray dan STAD.

\section{Hasil Penelitian dan Pembahasan}

Berdasarkan hasil penelitian yang dilakukan di SMA Negeri 15 Takengon pada kelas $\mathrm{X}$ dengan membandingkan model pembelajaran Course Review Horray (CRH) dengan STAD . Tes yang diberikan berupa tes 
uraian terdiri atas tes awal (Pre-Test) dan tes akhir (Post-test) yang dilakukan di kelas eksperimen I dan ekperimen II, kelas eksperimen I diberi perlakuan model Course Review Horray (CRH) sedangkan kelas ekperimen II menggunakan model STAD.

\section{Hasil}

Pada tes akhir uji normalitas dilakukan peneliti terhadap siswa dengan perlakuan berbeda yaitu siswa kelas eksperimen I diberi perlakuan dengan menggunakan model Course Review Horray (CRH) dan siswa kelas eksperimen II diberi perlakuan dengan menggunakan model STAD, hasil analisis dapat dilihat pada tabel 2 dibawah ini.

Tabel 2. Hasil Uji Normalitas Tes Akhir

\begin{tabular}{ccc}
\hline Tes Akhir & \multicolumn{2}{c}{ Kelas } \\
\cline { 2 - 3 } & $\begin{array}{c}\text { Eksperiman } \\
\text { I }\end{array}$ & $\begin{array}{c}\text { Eksperimen } \\
\text { II }\end{array}$ \\
\hline dk & 5,55 & 5,55 \\
\hline $\boldsymbol{x}^{2}$ hitung & 2,80 & 3,11 \\
\hline $\boldsymbol{x}^{2}$ tabel & 9,49 & 9,49 \\
\hline Kriteria & $2,80<9,49$ & $3,11<9,49$ \\
\hline Keterangan & Normal & Normal
\end{tabular}

Dari tabel 2 diperoleh nilai chi kuadrat untuk kelas eksperimen I yaitu $x^{2}{ }_{\text {hitung }}<x_{\text {tabel }}^{2}$ atau 2,80 $<9,49$ maka data tersebar dalam distribusi normal. Sedangkan untuk kelas eksperimen II yaitu $x^{2}{ }_{\text {hitung }}<x_{\text {tabel }}^{2}$ atau 3,11< 9,49 maka data tersebar dalam distribusi normal.

Uji homogen di lakukan untuk menunjukan bahwa kedua data tersebut merupakan data yang homogen atau sama. Pengujian uji homogen data ini dilakukan dengan menggunakan uji F.

Tabel 3. Hasil Uji Homogenitas Tes Akhir
Tes Akhir
Kelas

\begin{tabular}{ccc}
\hline & $\begin{array}{c}\text { Eksperiman } \\
\text { I }\end{array}$ & $\begin{array}{c}\text { Eksperimen } \\
\text { II }\end{array}$ \\
\hline $\begin{array}{c}\text { Jumlah } \\
\text { Siswa }\end{array}$ & 26 & 26 \\
\hline db & 25 & 25 \\
\hline $\mathbf{S}^{2}$ & 59,4 & 31,4 \\
\hline Fhitung $^{2}$ & 1,89 \\
\hline Ftabel & \multicolumn{3}{c}{1,96} \\
\hline Keterangan & \multicolumn{2}{c}{ Homogen } \\
\hline
\end{tabular}

Jumlah kedua sampel sama, dengan taraf signifikan $\alpha=0,05$. Dari tabel 3. di peroleh $F_{\text {hitung }}<F_{\text {tabel }}$ atau $1,89<1,96$, hal ini menunjukan bahwa varians dari kedua kelas eksperimen adalah homogen. Dengan demikian, sampel yang digunakan dapat mewakili populasi yang ada dan dapat dilanjutkan untuk uji hipotesis.

Hipotesis yang diajukan dalam penelitian ini adalah terdapat kemampuan pemahaman matematis siswa pada kelas $\mathrm{X}$ SMA Negeri 15 Takengon dengan perbandingan kelas eksperimen I menggunakan model Course Review Horray (CRH) dan kelas ekperimen II menggunakan model STAD.

Tabel 4. Hasil Uji Hipotesis Tes Akhir

\begin{tabular}{ccc}
\hline Tes Akhir & \multicolumn{2}{c}{ Kelas } \\
\cline { 2 - 3 } & $\begin{array}{c}\text { Eksperiman } \\
\text { I }\end{array}$ & $\begin{array}{c}\text { Eksperimen } \\
\text { II }\end{array}$ \\
\hline Jumlah & 26 & 26 \\
Siswa & & \\
\hline dk & 25 & 25 \\
\hline $\mathbf{S}^{\mathbf{2}}$ & 59,4 & 31,4 \\
\hline $\mathbf{S}$ & 7,70 & 5,60 \\
\hline S $_{\text {gabungan }}$ & \multicolumn{3}{|c}{35,6} \\
\hline thitung $^{3} 2,24$ \\
\hline ttabel & \multicolumn{3}{c}{2,01} \\
\hline Keterangan & \multicolumn{2}{c}{ Ho ditolak } \\
\hline
\end{tabular}


Dari Tabel 4 di peroleh $t_{\text {hitung }}>t_{\text {tabel }}$ dimana 2,44 $>2,01$, dengan taraf signifikan 0,05 dengan $\mathrm{dk}=26+26-2=50$, dengan demikian $\mathrm{H}_{0}$ ditolak dan $\mathrm{H}_{\mathrm{a}}$ diterima. Sehingga hal ini dapat dijelaskan bahwa model pembelajaran Course Review Horay (CRH) lebih baik dari STAD dalam meningkatkan pemahaman matematis siswa.

\section{Deskripsi Peningkatan Pemahaman Matematis}

Data N-gain diperoleh dari hasil perhitungan dengan menggunakan pre-test dan post-test. Data N-gain menunjukan peningkatan kemampuan pemahaman siswa setelah mengikuti pembelajaran sebagai berikut:

Tabel 5. Hasil Uji N-gain

\begin{tabular}{|c|c|c|c|}
\hline Eksperimen & $\begin{array}{l}\text { Nilai N- } \\
\text { gain }\end{array}$ & Kriteria & Keterangan \\
\hline $\begin{array}{c}\text { Model } \\
\text { Pembelajaran } \\
\text { Course Riview } \\
\text { Horray } \\
\text { (CRH) }\end{array}$ & $g=0,66$ & $\begin{array}{c}\text { Sedang } \\
0,3 \leq \\
g<0,7\end{array}$ & $\begin{array}{c}\text { Terjadi } \\
\text { Peningkatan } \\
\text { Kemampuan } \\
\text { Pemahaman } \\
\text { Matematis } \\
\text { Siswa }\end{array}$ \\
\hline $\begin{array}{c}\text { Model } \\
\text { Pembelajaran } \\
\text { STAD }\end{array}$ & $g=0,33$ & $\begin{array}{c}\text { Sedang } \\
0,3 \leq \\
g<0,7\end{array}$ & $\begin{array}{c}\text { Terjadi } \\
\text { Peningkatan } \\
\text { Kemampuan } \\
\text { Pemahaman } \\
\text { Matematis } \\
\text { Siswa }\end{array}$ \\
\hline
\end{tabular}

Dari data Tabel 5 di atas dapat dilihat bahwa peningkatan kemampuan pemahaman matematis yang menggunakan Model Pembelajaran Course Riview Horray (CRH) lebih signifikan sebesar $g=0,66$ dibanding dengan model pembelajaran STAD sebesar $g=0,33$.

Keterlaksanaan Model Pembelajaran Course Review Horay (CRH) dengan STAD Melalui
Kegiatan Pengamatan Aktivitas Guru dan Siswa

\section{Hasil Pengamatan Kinerja Guru}

Berdasarkan hasil pengamatan kinerja guru pada kelas eksperimen dan kelas kontrol, semua kegiatan yang tertuang sudah dilaksanakan oleh peneliti. Akan tetapi masih ada beberapa kegiatan yang belum terlaksana dengan baik. Namun, dengan adanya lembar pengamatan tersebut peneliti dapat mengetahui kekurangan dan segera memperbaiki pada pertemuan berikutnya. Berikut hasil pengamatan kinerja guru pada kelas eksperimen dan kelas kontrol:

Tabel 6. Hasil Pengamatan Kinerja Guru

\begin{tabular}{cccc}
\hline Kelas & $\begin{array}{c}\text { Perte } \\
\text { muan }\end{array}$ & $\begin{array}{c}\text { Persent } \\
\text { ase }\end{array}$ & Kriteria \\
\hline $\begin{array}{c}\text { Model } \\
\text { Pembela } \\
\text { jaran }\end{array}$ & 1 & $80 \%$ & $\begin{array}{c}\text { Cukup } \\
\text { Baik }\end{array}$ \\
\cline { 2 - 4 } $\begin{array}{c}\text { Course } \\
\text { Riview }\end{array}$ & 2 & $82 \%$ & Baik \\
\cline { 2 - 4 } $\begin{array}{c}\text { Horray } \\
\text { (CRH) }\end{array}$ & 4 & $89 \%$ & $\begin{array}{c}\text { Sangat } \\
\text { Baik }\end{array}$ \\
\hline $\begin{array}{c}\text { Rata-Rata } \\
\text { Model }\end{array}$ & 1 & $74 \%$ & $\begin{array}{c}\text { Sangat } \\
\text { Baik }\end{array}$ \\
$\begin{array}{c}\text { Pembela } \\
\text { jaran }\end{array}$ & 2 & $82 \%$ & Baik \\
STAD & 3 & $85 \%$ & Baik \\
\hline & 4 & $90 \%$ & Baik \\
\hline Rata-Rata & $83 \%$ & \\
\cline { 2 - 4 } & & & \\
\hline
\end{tabular}

Berdasarkan tabel di atas, diperoleh rata-rata kinerja guru dalam pengelolaan kelas pada kelas eksperimen sebesar $86 \%$ dan pada kelas kontrol sebesar 83\%. Dengan demikian dapat disimpulkan bahwa kinerja guru dalam pengelolaan kelas eksperimen maupun kelas kontrol dengan kategori baik. 


\section{Hasil Pengamatan Aktivitas Siswa}

Berdasarkan hasil pengamatan aktivitas siswa, sebagian besar aktivitas siswa yang diharapkan oleh peneliti telah terlaksana. Meskipun demikian, masih ada beberapa aktivitas yang hanya dilakukan oleh sedikit siswa seperti bertanya dan mempresentasikan hasl diskusi. Berikut hasil pengamatan aktivitas siswa pada kelas eksperimen dan kelas kontrol.

Tabel 7. Hasil Pengamatan Aktivitas Siswa

\begin{tabular}{|c|c|c|c|}
\hline Kelas & $\begin{array}{l}\text { Perte } \\
\text { muan }\end{array}$ & $\begin{array}{c}\text { Persen } \\
\text { tase }\end{array}$ & Kriteria \\
\hline \multirow{5}{*}{$\begin{array}{c}\text { Model } \\
\text { Pembelajaran } \\
\text { Course Riview } \\
\text { Horray (CRH) }\end{array}$} & 1 & $69 \%$ & Cukup \\
\hline & & & Baik \\
\hline & 2 & $75 \%$ & Baik \\
\hline & 3 & $85 \%$ & Baik \\
\hline & 4 & $88 \%$ & $\begin{array}{c}\text { Sangat } \\
\text { Baik }\end{array}$ \\
\hline \multicolumn{2}{|l|}{ Rata-Rata } & $79 \%$ & \\
\hline \multirow{4}{*}{$\begin{array}{c}\text { Model } \\
\text { Pembelajaran } \\
\text { STAD }\end{array}$} & 1 & $68 \%$ & $\begin{array}{c}\text { Cukup } \\
\text { Baik }\end{array}$ \\
\hline & 2 & $71 \%$ & $\begin{array}{c}\text { Cukup } \\
\text { Baik }\end{array}$ \\
\hline & 3 & $75 \%$ & Baik \\
\hline & 4 & $79 \%$ & Baik \\
\hline Rata-Rata & & $73 \%$ & \\
\hline
\end{tabular}

Berdasarkan hasil pengamatan aktivitas siswa, rata-rata persentase keaktifan siswa pada kelas eksperimen sebesar 79\% sedangkan rata-rata persentase keaktifan siswa pada kelas kontrol sebesar 73\%. Dengan demikian, dapat disimpulkan bahwa kinerja siswa dalam pengelolaan kelas baik kelas eksperiman maupun kelas kontrol dengan kategori baik. Di samping itu, persentase keaktifan siswa pada kelas eksperimen lebih tinggi dari pada kelas kontrol.
Indikator kemampuan pemahaman matematis siswa yang dimaksud dalam penelitian ini adalah indikator pengetahuan siswa terhadap pemahaman prosedur. Prosedur dalam matematika adalah langkah atau urutan atau cara yang digunakan untuk menyelesaikan tugas-tugas matematika yang maencakup langkah demi langkah dalam melakukan tugas. Berikut akan dikemukakan beberapa jawaban tes akhir yang dikerjakan siswa di kelas eksperimen menurut indikator pemahaman matematis siswa:

1) Menerjemahkan suatu permasalahan ke dalam bahasa matematis

Indikator pemahaman matematis ini meliputi kemampuan siswa dalam menerjemahkan suatu permasalahan ke dalam bahasa matematis. Dan indikator ini termasuk ke dalam kemampuan pemahaman prinsip, dimana pada pemahaman prinsip dalam matematika dapat berupa teorema atau dalil. Instrumen soal yang mengukur indikator ini salah satunya adalah soal no.1. Berikut ini adalah contoh soal dan jawaban siswa:

Anton berbelanja di koperasi sekolah membeli 5 buku, 6 pulpen, 2 penggaris ia seharga Rp.20.000,- sedang Susi mengeluarkan uang Rp.14.000,- untuk membeli 2 buku, 3 pulpen, dan 4 penggaris, Andi dengan uang Rp.6.000,- hanya dapat membeli 2 buku dan 2 pulpen, Raditya ingin membeli 3 buku, 4 pulpen, 1 penggaris berapakah uang yang harus dia persiapkan.

\section{Pembahasan}




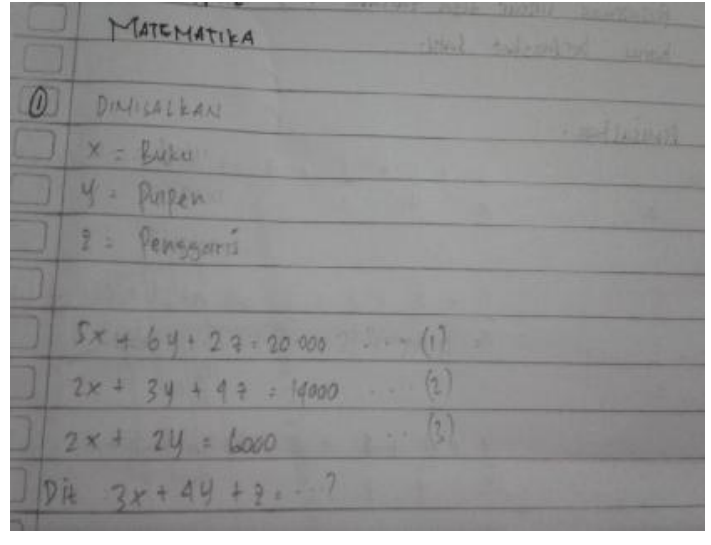

Gambar 1. Jawaban siswa terhadap soal no 1

Sebelum soal diselesaikan, terlebih dahulu siswa mengubah permasalahan yang ada ke dalam bahasa matematis. Jawaban pada Gambar 1 telah menunjukan bahwa kemampuan pemahaman matematis siswa pada indikator ini telah berkembang dengan baik. Siswa telah dapat menerjemahkan permasalahan ke dalam bahasa matematis.

2) Menyebut kembali konsep yang diperoleh dengan bahasanya sendiri

Menyebut kembali konsep yang diperoleh dengan bahasanya sendiri ini meliputi kemampuan siswa dalam memberikan jawaban dengan bahasanya sendiri. Dan termasuk ke dalam pemahaman konsep yaitu kemampuan dalam memahami konsep, operasi dan relasi dalam matematika. Instrumen soal yang mengukur indikator ini salah satunya adalah soal no.2. Berikut ini adalah contoh soal dan jawaban siswa.

Diberikan tiga persamaan: $\frac{1}{x}+\frac{1}{y}+\frac{3}{z}=9 ; \frac{1}{x}+$ $\frac{3}{y}+\frac{1}{z}=\frac{7}{3} ;$ dan $\frac{3}{x}+\frac{1}{y}+\frac{1}{z}=7$. Apakah termasuk sistem persamaan linear tiga variabel? Berikan alasanmu.

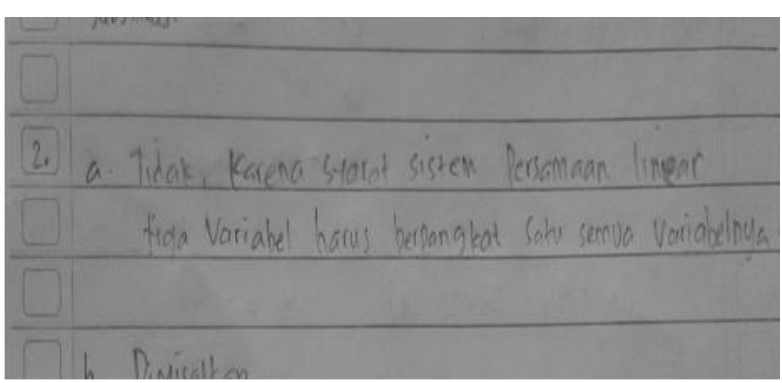

Gambar 2. Jawaban siswa terhadap soal no 2

Gambar 2 menunjukan bahwa kemampuan pemahaman matematis siswa untuk menyebutkan kembali yang diperoleh dengan bahasanya sendiri sudah berjalan dan berkembang dengan baik.

3) Menggunakan, memanfaatkan, dan memilih prosedur atau operasi tertentu dari suatu konsep secara algoritma serta mengaplikasikannya dalam pemecahan masalah

Indikator ini meliputi kemampuan siswa dalam menggunakan, memanfaatkan, dan memilih prosedur atau operasi tertentu dari suatu konsep secara algoritma serta mengaplikasikannya dalam pemecahan masalah. Dan indikator di atas termasuk ke dalam pemahaman prosedur dimana prosedur dalam matematika adalah langkah atau urutan atau cara yang digunakan untuk menyelesaikan tugas-tugas matematika yang maencakup langkah demi langkah dalam melakukan tugas. Instrumen soal yang mengukur indikator ini salah satunya adalah soal no.3. Berikut ini adalah contoh soal dan jawaban siswa.

Harga tiket suatu pertunjukkan adalah Rp60.000,00 untuk dewasa, Rp35.000,00 untuk pelajar, dan Rp25.000,00 untuk anak di bawah 12 tahun. Pada pertunjukkan seni dan budaya telah terjual 278 tiket dengan total penerimaan Rp13.000.000,00. Jika banyak tiket untuk dewasa yang telah terjual 10 tiket lebih sedikit dari dua kali banyak tiket pelajar 
yang terjual. Hitung banyak tiket yang terjual untuk masing-masing tiket.

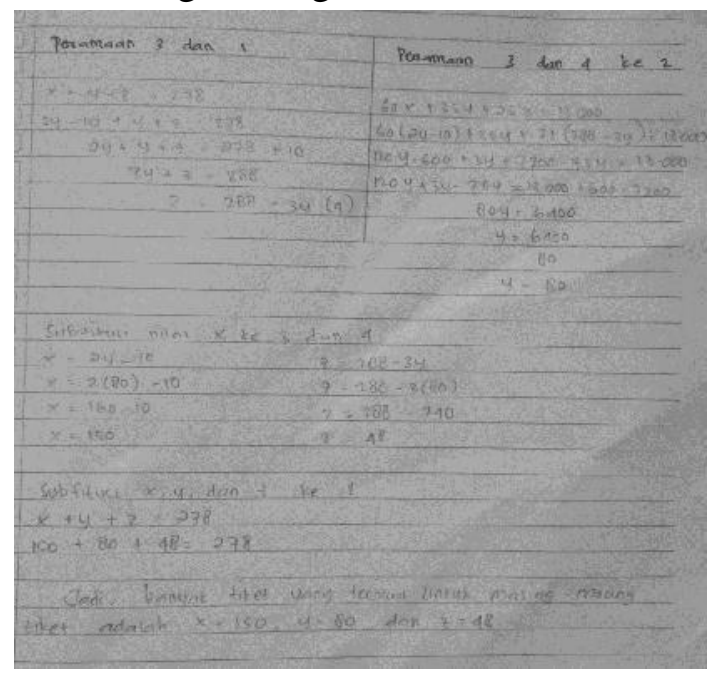

Gambar 3. Jawaban siswa terhadap soal no 3

Gambar 3 menunjukan bahwa siswa telah dapat menggunakan, memanfaatkan, dan memilih prosedur atau operasi tertentu dari suatu konsep secara algoritma serta mengaplikasikannya dalam pemecahan masalah sudah dikerjakan secara lengkap. Hal ini menunjukan bahwa kemampuan siswa pada indikator ini sangat berkembang dengan baik.

Kemampuan pemahaman matematis siswa yang diajarkan dengan model pembelajaran kooperatif tipe Course Review Horray (CRH) lebih baik dari pada kemampuan pemahaman siswa yang diajarkan dengan metode STAD. Hasil menunjukan bahwa kemampuan siswa menggunakan prosedur penyelesaian terhadap suatu masalah yang telah disajikan dengan menggunakan metode Course Review Horray (CRH) telah tercapai dengan baik. Dari pembahasan tersebut didukung oleh penelitian yang dilakukan oleh Firdaus bahwa model pembelajaran Course Review Horray (CRH) sangat sesuai untuk meningkatkan kemampuan matematis siswa karena dalam model ini siswa dituntut memahami materi yang di ajarkan, sehingga siswa harus bisa menyelesaikan soal sesuai dengan indikator kemampuan pemahaman matematis (Firdaus, 2014). Pernyataan tersebut juga didukung oleh Shoimin menyebutkan kelebihan model pembelajaran Course Review Horay (CRH) adalah: (1) menarik sehingga mendorong siswa terlibat di dalamnya; (2) tidak monoton karena di selingi sedikit hiburan sehingga suasananya tidak menegangkan; (3) siswa lebih semangat belajar; dan (4) melatih kerjasama (Shoimin, 2016).

Pembahasan bukan sekadar menarasikan data. Urutan pembahasan selaras urutan sajian data: cocokkan hipotesis/harapan dengan data. Berikan analisis atau tafsiran. Kembangkan gagasan atau argumentasi dengan mengaitkan hasil/ teori/ pendapat/ temuan sebelumnya, a.l. dengan membandingkan dengan temuan terdahulu, adakah pertimbangan teoretis, adakah kemungkinan manfaat, dan adakah kemungkinan keterbatasan hasil. Kembangkan argumen dalam paragraf. Isi pada bagian ini lebih-kurang 35\% dari total halaman naskah.

\section{Simpulan dan Saran}

\section{Simpulan}

Berdasarkan analisis data dan pengujian hipotesis yang telah dilakukan, dapat disimpulkan bahwa kemampuan pemahaman matematis siswa yang diajarkan dengan model pembelajaran kooperatif tipe Course Review Horray (CRH) lebih baik dari pada kemampuan pemahaman siswa yang diajarkan dengan metode STAD. Hasil menunjukan bahwa kemampuan siswa menggunakan prosedur penyelesaian terhadap suatu masalah yang telah disajikan dengan menggunakan metode Course Review Horray (CRH) telah tercapai dengan baik. Peningkatan 
kemampuan pemahaman matematis yang menggunakan Model Pembelajaran Course Riview Horray (CRH) lebih signifikan sebesar $g=0,66$ dibanding dengan model pembelajaran STAD sebesar $g=0,33$.

\section{Saran}

Berdasarkan hasil penelitian yang telah diperoleh, peneliti dapat memberikan saransaran sebagai berikut:

1. Bagi sekolah dan pihak guru khususnya, penelitian ini membuktikan bahwa penerapan Model Pembelajaran Kooperatif Tipe Course Review Horray (CRH) dapat meningkatkan kemampuan pemahaman matematis siswa sehingga dapat dijadikan sebagai alternatif pembelajaran yang dapat diterapkan dalam kelas.

2. Penelitian ini hanya ditujukan pada mata pelajaran matematika pada pokok bahasan sistem persamaan linear tiga variabel, oleh karena itu sebaiknya penelitian juga dilakukan pada pokok bahasan matematika lainnya.

\section{Daftar Pustaka}

Arahmah, I. Z., Suharno, \& Sudiman. (2017). Penerapan Model Pembelajaran Course Review Horay (Crh) Untuk Meningkatkan Pemahaman Konsep Jasa Dan Peranan Tokoh-Tokoh Kemerdekaan Pada Siswa Sekolah Dasar. Didaktika Dwija Indria ISSN: 2337-8786, 1-7.

Emzir. (2013). Model Penelitian Pendidikan. Jakarta: Rajawali.

Firdaus, R. (2014). Pengaruh Model Pembelajaran Aktif Course Review
Horay Terhadap Hasil Belajar Biologi Siswa Kelas VIII SMP Negeri 10 Batam. Riau: FKIP Universitas Kepulauan Riau.

Isjoni. (2010). Cooperative Learning Efektifitas Pembelajaran Kelompok. Bandung: Alfabeta.

Kurniasih, I. (2016). Ragam Pengembangan Model Pembelajaran untuk Peningkatan Profesionalitas Guru. Kata Pena.

Ruseffendi, E. (1998). Pengantar Kepada Membantu Guru Mengembangkan Kompetensinya dalam Pengaaran Matematika Untuk Meningkatkan CBSA. Bandung: Tarsito.

Shoimin. (2016). 68 Model Pembelajaran Inovatif dalam Kurikulum 2013. Yogyakarta: Ar-Ruzz Media.

Slavin, R. E. (1995). Cooperative Learning Theory, Research and Practice Massachusett. USA: Allymand dan Bacon.

Suherman, E. (2002). Strategi Pembelajaran Kontemporer. Bandung: UPI. 